\title{
Correction to: Macroeconomic Policy
}

\section{Correction to:}

\section{F. Langdana, Macroeconomic Policy,} Springer Texts in Business and Economics, https://doi.org/10.1007/978-3-319-32854-6

In the original version of the book, the following belated corrections have been incorporated:

In chapter 3, page 37, line 5 of the paragraph below Equation 3.4 has been changed from "hatched line" to "blue line".

In chapter 4 , page 75 , line 3 of the second paragraph has been changed from Fig. 4.9 to Fig. 4.11.

In chapter 5, page 90, in Equation 5.1, $\mathrm{C}$ has been underlined.

In chapter 7, page 152, in Equation 7.2, $\mathrm{C}$ and I have been underlined. Also, in Equation 7.3, A has been underlined.

The erratum book has been updated with the changes.

\footnotetext{
The updated versions of these chapters can be found at https://doi.org/10.1007/978-3-319-32854-6_3 https://doi.org/10.1007/978-3-319-32854-6_4 https://doi.org/10.1007/978-3-319-32854-6_5 https://doi.org/10.1007/978-3-319-32854-6_7 https://doi.org/10.1007/978-3-319-32854-6 